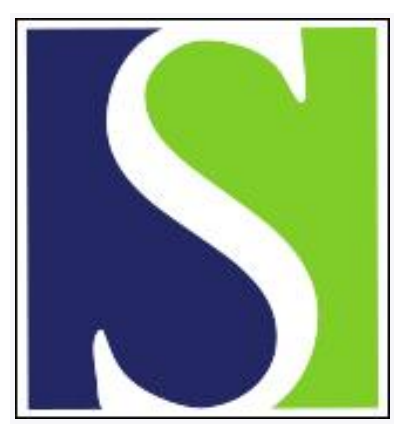

Scand J Work Environ Health 1984;10(4):245-251

https://doi.org/10.5271/sjweh.2330

Issue date: Aug 1984

Lung retention of antimony and arsenic in hamsters after the intratracheal instillation of industrial dust.

by Leffler P, Gerhardsson L, Brune D, Nordberg GF

This article in PubMed: www.ncbi.nlm.nih.gov/pubmed/6541805

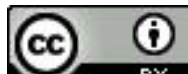




\title{
Lung retention of antimony and arsenic in hamsters after the intratracheal instillation of industrial dust
}

\author{
by Per Leffler, BSc, ${ }^{1}$ Lars Gerhardsson, MD, ${ }^{1,2}$ Dag Brune, PhD, ${ }^{3}$ Gunnar F Nordberg, MD, ${ }^{1}$
}

\begin{abstract}
LEFFLER P, GERHARDSSON L, BRUNE D, NORDBERG GF. Lung retention of antimony and arsenic in hamsters after the intratracheal instillation of industrial dust. Scand $J$ Work Environ Health 10 (1984) $245-251$. Airborne factory dust (with a volume median diameter of $5.0 \mu \mathrm{m}$ and a geometric standard deviation of $2.1 \mu \mathrm{m}$ ) from a Swedish copper smeltery contained antimony (Sb) (1.6 weight $\%$ ) and arsenic (As) (19 weight $\%$ ). The dust was neutron activated and intratracheally instilled in hamsters. In vivo measurements of lung clearance were undertaken of the radionuclides ${ }^{76} \mathrm{As},{ }^{122} \mathrm{Sb}$, and ${ }^{124} \mathrm{Sb}$. Comparison was made with pure substances of antimony trioxide $\left(\mathrm{Sb}_{2} \mathrm{O}_{3}\right)$ and arsenic trioxide $\left(\mathrm{As}_{2} \mathrm{O}_{3}\right)$. Two phases were recognized in the clearance curves. The approximate half-time for the initial phase was $13 \mathrm{~h}$ for $\mathrm{As}_{2} \mathrm{O}_{3}, 20 \mathrm{~h}$ for arsenic dust, about $40 \mathrm{~h}$ for $\mathrm{Sb}_{2} \mathrm{O}_{3}$, and about $30 \mathrm{~h}$ for antimony dust. The second phase had an approximate half-time of $20-40 \mathrm{~d}$ for $\mathrm{Sb}_{2} \mathrm{O}_{3}$ and antimony dust. Because of the short physical half-life of ${ }^{76} \mathrm{As}$, the second phase of the lung clearance was not possible to follow for $\mathrm{As}_{2} \mathrm{O}_{3}$ and arsenic dust. The observed differences in clearance were primarily related to the solubility of the dust particles in saline, while particle size seemed to be less important in this instillation experiment. The low solubility of antimony in factory dust combined with a long biological half-time may be of importance in explaining the observed lung accumulation of antimony in exposed workers. The greater solubility and shorter biological half-time restricted the lung retention of arsenic.
\end{abstract}

Key terms: biological half-time, lung clearance, neutron activation, particle solubility, radionuclides.

The dominating metal exposure for copper smelter workers originates from airborne dust in the work environment. In some earlier studies $(1,2,10)$ the lung accumulation of antimony ( $\mathrm{Sb}$ ), arsenic (As), and several other elements in deceased copper smelter workers were reported. The greatest difference between the workers and referents was found for antimony. Occupational exposure to antimony has, however, seldom been studied $(3,5,6)$.

In the present investigation pulmonary retention after the intratracheal instillation of airborne industrial dust containing antimony and arsenic has been measured in hamsters. The dust was neutron activated. External in vivo measurements were undertaken.

\section{Materials and methods}

\section{Workshop dust}

Arsenic in the airborne dust of the copper smeltery under study appears mainly as oxides but also as sul-

1 Department of Environmental Medicine, University of Umeå, S-901 87 Umeá, Sweden.

2 Department of Medicine, University of Umeå, S-901 87 Umeå, Sweden.

3 Scandinavian Institute of Dental Materials, Oslo 3, Norway.

Reprint requests to: Mr P Leffler, Department of Environmental Medicine, University of Umeå, S-901 87 Umeá, Sweden. fides $(5,13,17)$. Antimony may be present as oxides and sulfides.

Our investigation has been made possible by the kind assistance of the Health and Safety Department at a big Swedish copper smeltery $(4,19)$. Airborne dust was collected from one selected workplace, the arsenic refinery. With the use of a high-volume sampler (Staplex type TFI A-2) with a glass fiber filter of $0.6 \mu \mathrm{m}$ porosity, dust was sampled during nine shifts $(72 \mathrm{~h})$. Dust $(1,958 \mathrm{mg})$ was collected from a total air volume of about $7,000 \mathrm{~m}^{3}$ and eluated with acetone. The resulting $1,845 \mathrm{mg}$ was used in the experiments. In our study pure substances of antimony trioxide $\left(\mathrm{Sb}_{2} \mathrm{O}_{3}\right)$ (Merck, analytical grade) and arsenic trioxide $\left(\mathrm{As}_{2} \mathrm{O}_{3}\right)$ (Matthey, specpure $99.99997 \%$ ) were used for comparison.

\section{Chemical and physical properties}

The particle size distribution of the dust was determined with a Coulter counter model TA II. The factory dust had a volume median diameter of $5.0 \mu \mathrm{m}$ with a geometric standard deviation (GSD) of $2.1 \mu \mathrm{m}$. For the comparison substances $\mathrm{Sb}_{2} \mathrm{O}_{3}$ and $\mathrm{As}_{2} \mathrm{O}_{3}$ the volume median diameters were 7.0 (GSD 2.2) $\mu \mathrm{m}$ and 14.0 (GSD 2.6) $\mu \mathrm{m}$, respectively. In a separate experiment two other size fractions of $\mathrm{Sb}_{2} \mathrm{O}_{3}$ particles were used in order to estimate the degree of influence of particle size on the clearance characteristics. The volume median diameters of 
these fractions were 13.3 (GSD 2.3) $\mu \mathrm{m}$ and 19.5 (GSD 3.1) $\mu \mathrm{m}$. The elemental composition of the dust was determined by atomic absorption after dissolution in concentrated nitric acid (Analytica $A B$, Stockholm, Sweden), emission spectrography (Analytica AB, Stockholm, Sweden; Kjeller, Norway), or neutron activation analysis (Tekniska Röntgencentralen AB, Stockholm, Sweden) according to methods described by Sjöstrand (16) and Samsahl et al (15). The solubility of the dust and the comparison substances was determined $24 \mathrm{~h}$ after suspension in a $0.9 \%$ saline solution at room temperature. Fractions of the suspension $(0.2-0.4 \mathrm{ml})$ were centrifuged $(g=5,000)$ for $4 \mathrm{~min}$, and the radionuclides $\left({ }^{76} \mathrm{As}\right.$ and ${ }^{122} \mathrm{Sb}$ ) in the supernatant and sediment were measured.

\section{Neutron activation}

The dust and comparison substances were irradiated at the nuclear reactor in Kjeller, Norway. The dust sample was treated in two different ways. One part $(100.0 \mathrm{mg}$ ) was irradiated to obtain the radionuclides ${ }^{122} \mathrm{Sb}\left(\mathrm{t}_{1 / 2}=2.8 \mathrm{~d}\right)$ and ${ }^{124} \mathrm{Sb}\left(\mathrm{t}_{1 / 2}=60.3 \mathrm{~d}\right)$. A neutron flux of $2 \times 10^{13} \mathrm{n} /\left(\mathrm{cm}^{2} \cdot \mathrm{s}\right)$ was applied for $4 \mathrm{~d}$. This sample (antimony dust) was stored for four months before the experiments started in order to eliminate the influence of radiation from short-lived isotopes such as ${ }^{76} \mathrm{As}$. Another part $(20.9 \mathrm{mg})$ was irradiated only $5 \mathrm{~h}$ at the flux $5 \times 10^{12} \mathrm{n} /\left(\mathrm{cm}^{2} \cdot \mathrm{s}\right)$ to obtain ${ }^{76} \mathrm{As}\left(\mathrm{t}_{1 / 2}=26.5 \mathrm{~h}\right)$ in the arsenic dust. This part was used $2 \mathrm{~d}$ after activation, when ${ }^{76}$ As activity was predominant.

The comparison substance $\mathrm{Sb}_{2} \mathrm{O}_{3}$ (s) was irradiated $4 \mathrm{~d}$ and $\mathrm{As}_{2} \mathrm{O}_{3}$ (s) $2 \mathrm{~d}$ before use with a neutron

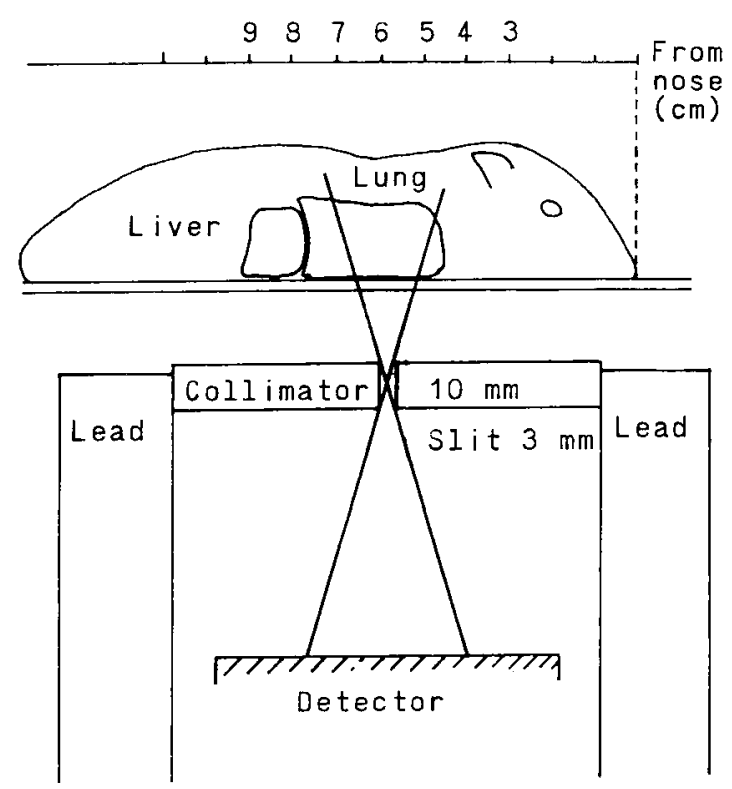

Figure 1. External measurements of the retention of radioactive substances. flux of $5 \times 10^{12} \mathrm{n} /\left(\mathrm{cm}^{2} \cdot \mathrm{s}\right)$ for $1 \mathrm{~h}$ to form ${ }^{122} \mathrm{Sb}$, ${ }^{124} \mathrm{Sb}$, and ${ }^{76} \mathrm{As}$.

\section{Animals}

The animals used were male adult [29 weeks, 124 (SD 16) g] Syrian golden hamsters (Quality 2, Bantin and Kingman, Hull, England). The animals were kept separately in plastic cages. The wood chips (Torrax, Anticimex) in the cages were changed every week, and on the same occasion the animals were weighed. The animals were fed rat and mouse pellets (R3, Ewos-Anticimex) and tap water ad libitum with a weekly addition of cabbage. The cages were placed in a room with a temperature of $20-22^{\circ} \mathrm{C}$, a humidity of $40-50 \%$, an air exchange of approximately seven times per hour, and a 12-h light/dark cycle. The animals were acclimatized three to four weeks before the experiments. After two weeks each animal was checked for their instillation tolerance by the instillation of a $0.2-\mathrm{ml}$ saline solution. On the basis of these pretests 20 animals were selected for the experiments and divided into four groups.

\section{Instillation}

The activated substances, delivered in quartz ampuls, were suspended in $0.9 \%$ saline and diluted to the appropriate activity of the studied elements (10-100 $\mathrm{kBq}$ per instillation dose). The calculated instilled doses in milligrams per kilogram of body weight were as follows: arsenic $\left(\mathrm{As}_{2} \mathrm{O}_{3}\right) 1.43$ (SEM 0.23); antimony $\left(\mathrm{Sb}_{2} \mathrm{O}_{3}\right) 1.52$ (SEM 0.09); arsenic (dust) 1.46 (SEM 0.18); and antimony (dust) 0.04 (SEM 0.001).

In the experiment with different size fractions of $\mathrm{Sb}_{2} \mathrm{O}_{3}$ particles the doses used were 0.23 (SEM 0.02) and 0.33 (SEM 0.06 ) $\mathrm{mg}$ of antimony/ $\mathrm{kg}$ of body weight. Each animal received one single dose by the intratracheal instillation of a suspension containing either $\mathrm{As}_{2} \mathrm{O}_{3}, \mathrm{Sb}_{2} \mathrm{O}_{3}$, arsenic dust, or antimony dust. The technique has been described by Saffiotti et al (14). A special instillation syringe (12) was used. Prior to instillation each animal was anesthetized by an intraperitoneal injection of Brietal Sodium (Lilly), $50 \mathrm{mg} / \mathrm{kg}$ of body weight, and placed on its back on a slanted board.

After vigorous stirring $0.2 \mathrm{ml}(0.1 \mathrm{ml}$ in six cases $)$ of the suspensions was immediately instilled. Each animal was then placed in its cage to recover 5 to 10 min prior to the external lung clearance measurements. Instillations were performed at the following times after the suspension of dust in saline: $\mathrm{As}_{2} \mathrm{O}_{3}$ $3 \mathrm{~h}$, arsenic dust $3 \mathrm{~h}, \mathrm{Sb}_{2} \mathrm{O}_{3} 3 \mathrm{~h}$, antimony dust $3 \mathrm{~h}$.

One animal from each group was used as a reference. The reference animals were sacrificed immediately after the instillation with an overdose of Brietal Sodium intraperitoneally.

In order to fix the instilled material, $0.2-0.5 \mathrm{ml}$ of Formalin solution $(10 \%)$ was instilled to inhibit 
ciliary activity of the bronchial mucosa. The animals were then frozen to a temperature of $-20^{\circ} \mathrm{C}$ and kept frozen throughout the experiments.

\section{External lung clearance measurements}

The lung clearance of the labeled components was monitored externally. The experimental set-up consisted of a sodium iodide (thallium) crystal detector [NaI(Tl) detector] (Harshaw, size $76 \times 76 \mathrm{~mm}$ ) with a resolution of $7.9 \%$, combined with a multichannel analyzer [Nuclear Data (ND)-60]. The different radionuclides were monitored at their typical spectral energy peaks, which were $559 \mathrm{keV}$ for ${ }^{76} \mathrm{As}, 564 \mathrm{keV}$ for ${ }^{122} \mathrm{Sb}$, and $603 \mathrm{keV}$ for ${ }^{124} \mathrm{Sb}$.

The geometric set-up aimed at excluding radiation from tissues outside the thoracic region (figure 1). A lead collimator was used with a thickness of $10 \mathrm{~mm}$ and a slit $(3 \times 50 \mathrm{~mm})$ placed transversally to the animal.

The gamma activity was measured at two partly overlapping positions, 5 and $6 \mathrm{~cm}$ from the nose of the animal, to eliminate errors due to an irregular distribution in the lungs. A plastic mold restricted the mobility of the animal being measured.

The number of counts in a certain energy interval was registered as the sum of the net area in a defined energy region and its corresponding background area. The general background level was subtracted. The mean value of the measured number of counts in the two positions was used in the calculations.

\section{Tissue measurements}

The external measurements of arsenic $\left(\mathrm{As}_{2} \mathrm{O}_{3}\right.$ and arsenic dust) were discontinued after about $43 \mathrm{~h}$ due to the short physical half-life of ${ }^{76} \mathrm{As}$. The animals exposed to antimony were studied for $190 \mathrm{~h}$. After these time intervals the animals were sacrificed with an intraperitoneal overdose of Brietal Sodium. Each animal was dissected and the tissue concentrations of arsenic and antimony were measured in the lung lobes, liver, kidneys, trachea, and stomach by gamma counting. Standards were prepared from the suspensions used for instillation. The measurements were performed on a Packard auto gamma scintillation counting instrument with a $\mathrm{NaI}(\mathrm{Tl})$-crystal well detector (Packard, dimensions $51 \times 51 \mathrm{~mm}$ ), with a resolution of about $10 \%$. The samples were measured repeatedly for $5 \mathrm{~min}$ during a time interval of several days, and the radionuclides were identified by their half-lives.

\section{Results}

\section{Dust}

The elemental composition of the dust is displayed in table 1. Arsenic constituted $19 \%$ and antimony $1.6 \%$ of the dust collected.
The radionuclides were identified by their physical half-lives as measured in the reference animals. The half-life of $\mathrm{As}_{2} \mathrm{O}_{3}\left(\mathrm{t}_{1 / 2}=26.4 \mathrm{~h}\right)$ and $\mathrm{Sb}_{2} \mathrm{O}_{3}\left(\mathrm{t}_{1 / 2}=\right.$ $3.1 \mathrm{~d})$ agreed with literature values (18) for ${ }^{76} \mathrm{As}$ and ${ }^{122} \mathrm{Sb}$. The calculated half-lives for arsenic dust $\left(\mathrm{t}_{1 / 2}=25.8 \mathrm{~h}\right)$ and antimony dust $\left(\mathrm{t}_{1 / 2}=58 \mathrm{~d}\right)$ agreed with those of ${ }^{76} \mathrm{As}$ and ${ }^{124} \mathrm{Sb}$.

\section{Lung retention}

In figures $\mathbf{2}$ and 3 the lung retention curves are shown for the four test groups. Two phases can be distinguished in the elimination of $\mathrm{Sb}_{2} \mathrm{O}_{3}$ and antimony dust. In an initial phase around $20 \%$ of the instilled $\mathrm{Sb}_{2} \mathrm{O}_{3}$ and about $35 \%$ of the antimony dust was eliminated during the first $20 \mathrm{~h}$. Due to experimental uncertainties it was difficult to estimate the exact clearance half-time of $\mathrm{Sb}_{2} \mathrm{O}_{3}$ and antimony dust. The short half-life of ${ }^{76} \mathrm{As}$ restricted a prolonged clearance study. These groups could only be studied for $43 \mathrm{~h}$. Thus a possible second phase of elimination could not be quantified for arsenic. The calculated biological clearance half-times for the initial $(0-20 \mathrm{~h})$ and second $(20-200 \mathrm{~h})$ phases are given in table 2 .

The retention of the different substances in the lung region after $43 \mathrm{~h}$ were calculated to be (mean values) $7 \%$ for $\mathrm{As}_{2} \mathrm{O}_{3}, 35 \%$ for arsenic dust, $75 \%$ for $\mathrm{Sb}_{2} \mathrm{O}_{3}$, and $60 \%$ for antimony dust.

The arsenic in the arsenic dust had a higher retention than $\mathrm{As}_{2} \mathrm{O}_{3}$ (figure 2). The retention of arsenic was lower in both groups than the retention of antimony given as $\mathrm{Sb}_{2} \mathrm{O}_{3}$. The retention of antimony in antimony dust was higher than the retention of arsenic in arsenic dust (figures $2 \& 3$ ).

The solubility of the particles, as estimated $24 \mathrm{~h}$ after suspension in $0.9 \%$ saline $\left(20^{\circ} \mathrm{C}\right)$, were as follows:

${ }^{76} \mathrm{As}: \mathrm{As}_{2} \mathrm{O}_{3} 50 \%(2.5 \mathrm{~g} / \mathrm{l})$, arsenic dust $25 \%(1.6 \mathrm{~g} / 1)$; ${ }^{122} \mathrm{Sb}: \mathrm{Sb}_{2} \mathrm{O}_{3} 4 \%(4.5 \mathrm{~g} / \mathrm{l})$, antimony dust $4 \%(0.14 \mathrm{~g} / \mathrm{l})$.

Table 1. Elements of hygienic significance in the dust sample (weight percentagea).

\begin{tabular}{lrll}
\hline Component & $\begin{array}{c}\text { Weight } \\
\text { percentage }\end{array}$ & Component & $\begin{array}{l}\text { Weight } \\
\text { percentage }\end{array}$ \\
\hline Arsenic $^{\mathrm{b}}$ & 19.0 & Magnesium $^{\mathrm{c}}$ & 0.15 \\
Iron $^{\mathrm{b}}$ & 11.4 & Titanium $^{\mathrm{c}}$ & 0.06 \\
Lead $^{\mathrm{c}}$ & 6.2 & Nickelc $^{\mathrm{c}}$ & 0.05 \\
Copper $^{\mathrm{b}}$ & 4.8 & Manganese $^{\mathrm{c}}$ & 0.02 \\
Selenium $^{\mathrm{b}}$ & 4.0 & Vanadium $^{\mathrm{c}}$ & 0.003 \\
Bismuth $^{\mathrm{c}}$ & 2.8 & Cadmiumm $^{\mathrm{b}}$ & $0.064 \times 10^{-2}$ \\
Zinc $^{\mathrm{b}}$ & 1.6 & Chromiumm $^{\mathrm{b}}$ & $0.045 \times 10^{-2}$ \\
Antimony $^{\mathrm{b}}$ & 1.6 & Cobalt $^{\mathrm{b}}$ & $0.042 \times 10^{-2}$ \\
Aluminum $^{\mathrm{c}}$ & 1.4 & Silverb $^{\mathrm{b}}$ & $0.033 \times 10^{-2}$ \\
Mercury $^{\mathrm{b}}$ & 1.2 & Molybdenumb $^{\mathrm{b}}$ & $0.010 \times 10^{-2}$ \\
Tin $^{\mathrm{b}}$ & 0.26 & Lanthanum $^{\mathrm{b}}$ & $0.006 \times 10^{-2}$ \\
\hline
\end{tabular}

a The components appeared as silicates, oxides and sulfides.

b Analyzed by neutron activation analysis.

c Analyzed by atomic absorption spectrophotometry. 


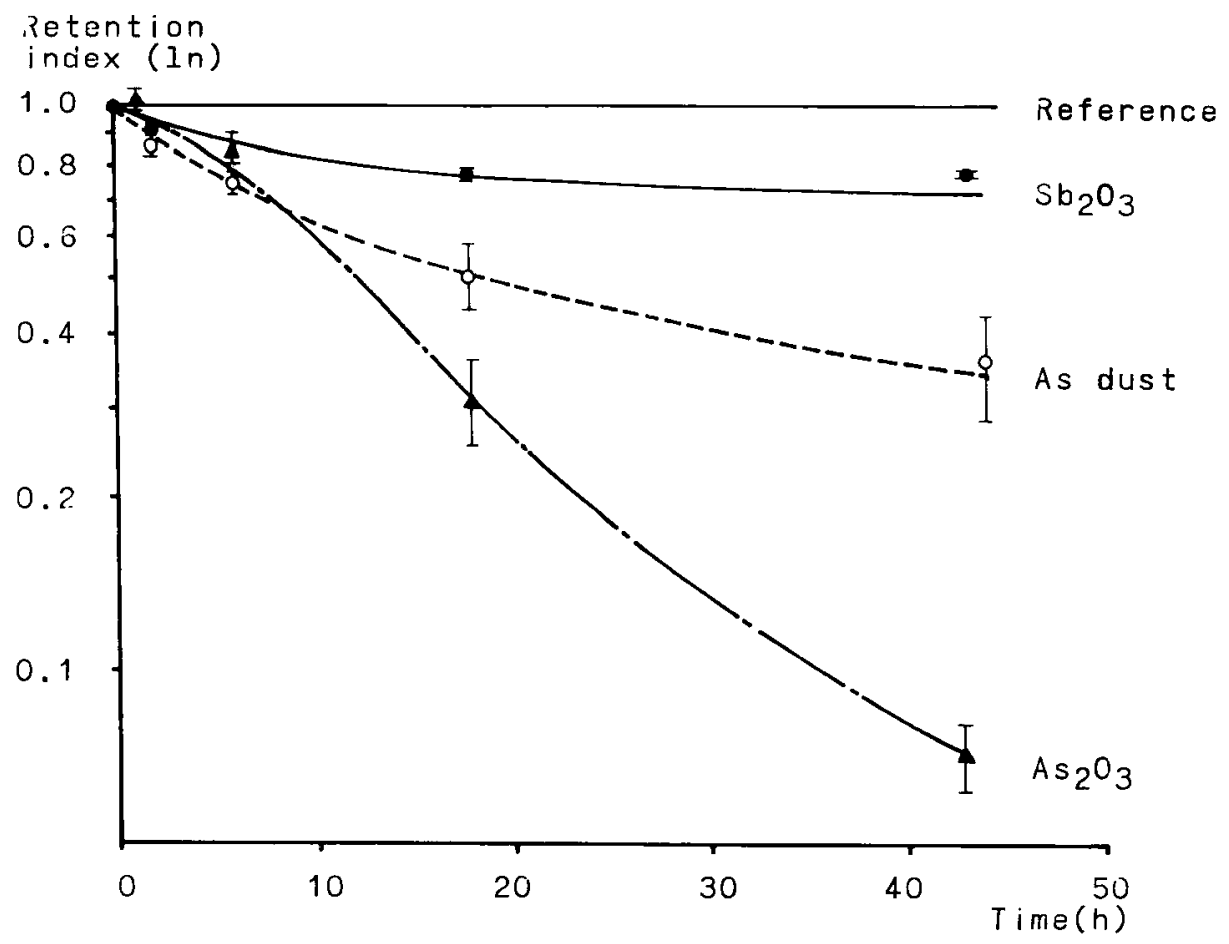

Figure 2. Lung retention [mean \pm standard error of the mean (SEM)] of antimony and arsenic in hamsters after the intratracheal instillation of antimony trioxide $\left(\mathrm{Sb}_{2} \mathrm{O}_{3}\right)$, arsenic $(\mathrm{As})$ dust, and arsenic trioxide $\left(\mathrm{As}_{2} \mathrm{O}_{3}\right)$. $($ Reference $=$ values obtained for the respective references measured at the same time as the exposed animals).

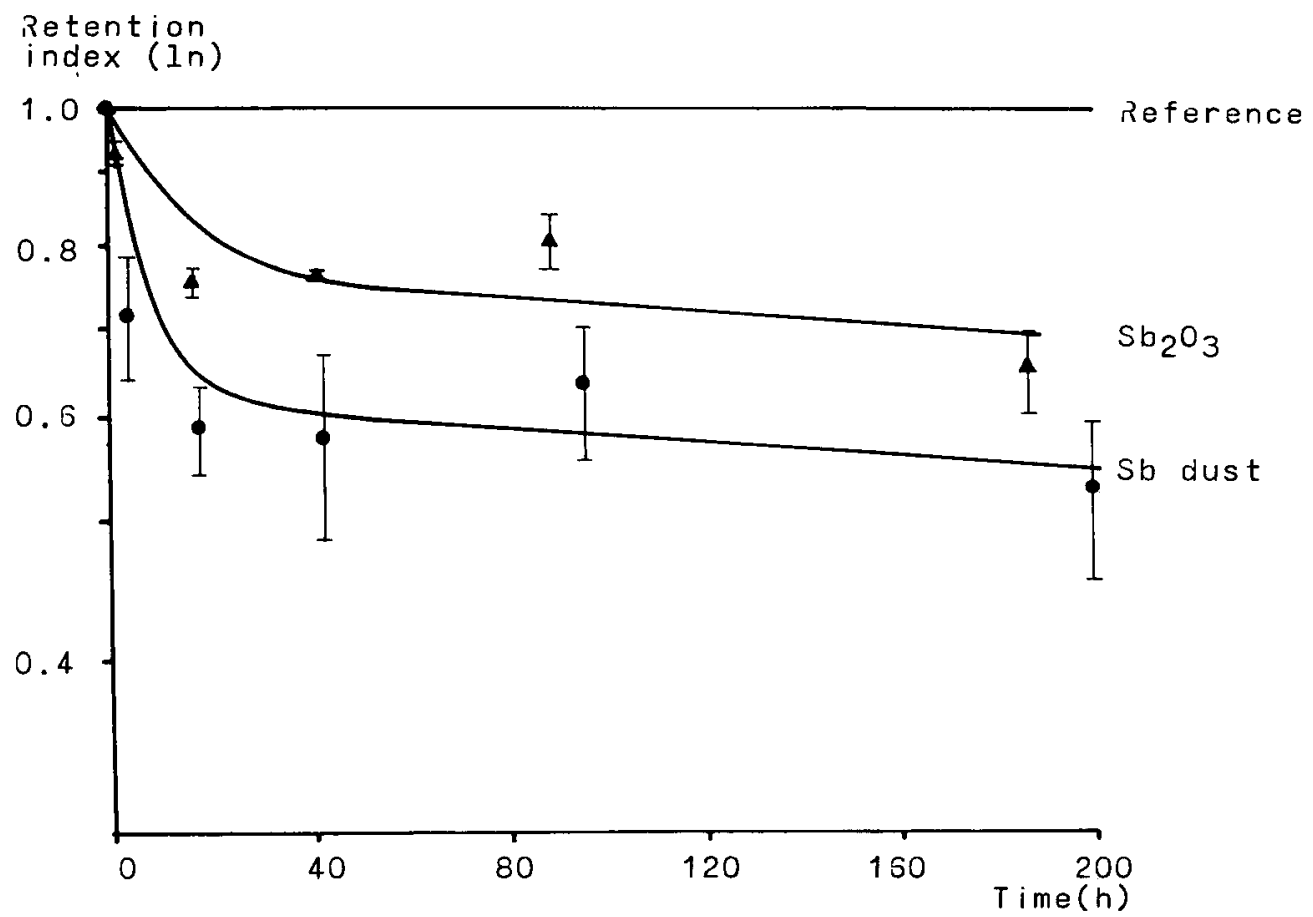

Figure 3. Lung retention [mean \pm standard error of the mean (SEM)] of antimony in hamsters after the intratracheal instillation of antimony trioxide $\left(\mathrm{Sb}_{2} \mathrm{O}_{3}\right)$ and antimony $(\mathrm{Sb})$ dust. The measurements of antimony dust were made after the full decay of ${ }_{76}$ arsenic. (Reference $=$ values obtained for the respective references measured at the same time as the exposed animals). 


\section{Tissue retention}

Tissue retention is presented in table 3 as the percentage of instilled dose. In general the lung values indicate a good validity of the external measurements although the latter values are somewhat higher. Since the values measured for the other tissues were low, a very low influence on the external lung clearance measurements can be expected. However, a minor contribution from the liver cannot be excluded.

In agreement with the external measurements the remaining percentage of the instilled arsenic dose measured in lung tissue was higher in the group exposed to arsenic dust than in the group exposed to $\mathrm{As}_{2} \mathrm{O}_{3}$. The levels in other tissues were lower in arsenic dust animals than in the $\mathrm{As}_{2} \mathrm{O}_{3}$ ones, ie, the stomach and kidneys of the arsenic dust animals contained about $0.1 \%$ arsenic and liver arsenic was not detectable, while liver arsenic from the $\mathrm{As}_{2} \mathrm{O}_{3}$ animals was $3 \%$ and that in the stomach and kidneys around $1 \%$ or less.

The tissue retention pattern in the groups exposed to antimony dust $(5 \mu \mathrm{m})$ or $\mathrm{Sb}_{2} \mathrm{O}_{3}(7.0 \mu \mathrm{m})$ and sacrificed after $190 \mathrm{~h}$ is also presented in table 3 . The lung tissue values are in fair agreement with the external measurements, a result showing a somewhat higher retention for antimony administered as $\mathrm{Sb}_{2} \mathrm{O}_{3}$ as compared to administration as antimony dust. The amount of antimony in liver was, for these two groups, approximately one-tenth the lung content. For the trachea and stomach the values were $0.2 \%$ or less.

The results of the experiments with different size fractions of $\mathrm{Sb}_{2} \mathrm{O}_{3}$ particles are also presented in table 3. When compared to the values of the original experiment with $\mathrm{Sb}_{2} \mathrm{O}_{3}(7.0 \mu \mathrm{m})$, there was a tendency for larger particles to have a somewhat lower lung retention than the smaller particles. This phenomenon was accompanied by higher values for, especially, the liver but also the stomach and kidney, and therefore a higher flux of the element through the body was indicated. This occurrence might have been due to mucociliary transport and gastrointestinal absorption, as indicated by the higher value for the larger particles in the stomach and trachea.

\section{Discussion}

\section{Particle properties}

The present study of the factory dust determined the elemental composition and particle size of the total dust, and it did not reveal the distribution of elements among various size fractions. The latter type of information is obviously of great importance when the pulmonary deposition pattern after inhalation is being evaluated, but it could be expected to be of less importance for the present instillation study. The measured volume median diameter varied between the dust from the smeltery [5.0 (GSD 2.1) $\mu \mathrm{m}]$ and the comparison substances $\mathrm{Sb}_{2} \mathrm{O}_{3}[7.0$ (GSD 2.2) $\mu \mathrm{m}$ ] and $\mathrm{As}_{2} \mathrm{O}_{3}$ [14.0 (GSD 2.6) $\mu \mathrm{m}$ ]. In order to clarify the influence of the particle sizes on the clearance pattern in this instillation study, we repeated the experiment with two other size fractions of $\mathrm{Sb}_{2} \mathrm{O}_{3}$ (13.3 and $19.5 \mu \mathrm{m}$ ). As seen from table 3, particle size had a limited influence on pulmonary retention after intratracheal instillation. The particle size in our study had less influence on the clearance pattern than the solubility. In view of the observations made in this study, the main difference between $\mathrm{As}_{2} \mathrm{O}_{3}$, arsenic dust, $\mathrm{Sb}_{2} \mathrm{O}_{3}$, and antimony dust appears to be due to solubility.

\section{Solubility and clearance}

Long-term clearance often has a positive correlation with the in vitro solubility of various dusts and thus indicates that the in vivo solubility is an important factor in this clearance phase $(7,8)$. In vitro studies have shown that the fast lung clearance of $\mathrm{As}_{2} \mathrm{O}_{3}$ is, to a substantial degree, caused by dissolution (11). The solubility of $\mathrm{As}_{2} \mathrm{O}_{3}$ in our experiment agreed with the value of $68 \%$ (concentration $50 \mathrm{mg} \mathrm{As} / 1$ at

Table 2. Calculated biological half-time $\left(t_{1 / 2}\right)$ in lung tissue.

\begin{tabular}{lcc}
\hline Substance & $\begin{array}{c}\text { Initial phase } \\
t_{1 / 2}(\mathrm{~h})\end{array}$ & $\begin{array}{c}\text { Second phase } \\
\mathrm{t}_{1 / 2}(\mathrm{~d})\end{array}$ \\
\hline $\begin{array}{l}\text { Arsenic trioxide } \\
\text { Arsenic dust }\end{array}$ & 13 & $\cdot$ \\
Antimony trioxide & 20 & $\cdot$ \\
Antimony dust & about 40 & $20-40$ \\
\hline
\end{tabular}

Table 3. Percentage of the instilled dose found in different organs after the intratracheal instillation of arsenic trioxide $\left(\mathrm{As}_{2} \mathrm{O}_{3}\right)$, arsenic dust (As dust), antimony trioxide $\left(\mathrm{Sb}_{2} \mathrm{O}_{3}\right)$, and antimony dust ( $\mathrm{Sb}$ dust) in Syrian hamsters. ( $\mathrm{N}=$ number in group, nd = not detected, VMD = volume median diameter, SEM = standard error of the mean)

\begin{tabular}{|c|c|c|c|c|c|c|c|c|c|c|c|c|}
\hline \multirow{2}{*}{ Group } & \multirow{2}{*}{$\begin{array}{c}\text { Particle } \\
\text { size (VMD) } \\
(\mu \mathrm{m})\end{array}$} & \multirow{2}{*}{$\begin{array}{l}\text { Survival } \\
\text { time (h) }\end{array}$} & \multicolumn{2}{|c|}{ Lung } & \multicolumn{2}{|c|}{ Liver } & \multicolumn{2}{|c|}{ Kidney } & \multicolumn{2}{|c|}{ Stomach } & \multicolumn{2}{|c|}{ Trachea } \\
\hline & & & Mean & SEM & Mean & SEM & Mean & SEM & Mean & SEM & Mean & SEM \\
\hline $\begin{array}{l}\text { As dust }(\mathrm{N}=3) \\
\mathrm{As}_{2} \mathrm{O}_{3}(\mathrm{~N}=4) \\
\mathrm{Sb} \text { dust }(\mathrm{N}=4) \\
\mathrm{Sb}_{2} \mathrm{O}_{3}(\mathrm{~N}=4) \\
\mathrm{Sb}_{2} \mathrm{O}_{3}(\mathrm{~N}=3) \\
\mathrm{Sb}_{2} \mathrm{O}_{3}(\mathrm{~N}=4)\end{array}$ & $\begin{array}{r}5.0 \\
14.0 \\
5.0 \\
7.0 \\
13.3 \\
19.5\end{array}$ & $\begin{array}{r}43 \\
43 \\
190 \\
190 \\
190 \\
190\end{array}$ & $\begin{array}{r}28.8 \\
5.8 \\
49.0 \\
59.8 \\
48.9 \\
44.5\end{array}$ & $\begin{array}{l}1.5 \\
1.8 \\
1.2 \\
2.4 \\
1.5 \\
5.9\end{array}$ & $\begin{array}{r}\text { nd } \\
3.0 \\
4.6 \\
7.2 \\
9.2 \\
12.6\end{array}$ & $\begin{array}{l}\text { nd } \\
1.6 \\
0.3 \\
0.6 \\
0.3 \\
1.4\end{array}$ & $\begin{array}{l}0.1 \\
0.5 \\
0.3 \\
0.1 \\
0.3 \\
0.3\end{array}$ & $\begin{array}{l}0.01 \\
0.1 \\
0.02 \\
0.002 \\
0.03 \\
0.05\end{array}$ & $\begin{array}{l}0.1 \\
1.2 \\
0.2 \\
0.2 \\
0.6 \\
0.2\end{array}$ & $\begin{array}{l}0.01 \\
0.2 \\
0.02 \\
0.01 \\
0.2 \\
0.06\end{array}$ & $\begin{array}{l}0.1 \\
0.2 \\
0.1 \\
0.2 \\
0.2 \\
0.4\end{array}$ & $\begin{array}{l}0.03 \\
0.1 \\
0.02 \\
0.07 \\
0.05 \\
0.3\end{array}$ \\
\hline
\end{tabular}


$37^{\circ} \mathrm{C}$ ) reported by Pershagen et al (11). The lower solubility of ${ }^{76} \mathrm{As}$ in the arsenic dust might be explained by less soluble arsenic compounds in the dust. The slow elimination of $\mathrm{Sb}_{2} \mathrm{O}_{3}$ and antimony dust in the second phase may be partly caused by low solubility.

\section{Biological half-time}

Although there were certain difficulties in estimating the biological half-time of antimony in pulmonary tissues precisely, it is obvious that antimony dust, and $\mathrm{Sb}_{2} \mathrm{O}_{3}$ are retained to a much larger extent in the lung than arsenic dust and $\mathrm{As}_{2} \mathrm{O}_{3}$.

Tissue levels of antimony were higher than those of arsenic in the lungs of dead smelter workers from the smeltery under study (1). Such a relationship may be explained by the considerably longer biological halftime of antimony compared to that of arsenic, as demonstrated in the present study. However, it should be noted that the relative proportions of antimony and arsenic are known only for a small number of dust samples and that its general representativeness for all conditions at the factory, which also has other workplaces, cannot be evaluated at present.

\section{Comparison with human exposure}

Wester et al (19) studied arsenic and selenium in lung, liver, and kidney tissues from deceased smelter workers from the company from which the present dust samples originated. In a comparison with the reference values, a sevenfold increase of arsenic in the lung tissues was observed. After the workers were retired, the arsenic content decreased with time in the liver but not in lung tissue, a finding indicating a longer biological half-time in the lung.

In our experiments we noted a rapid initial phase but with a longer biological half-time for arsenic in dust than for the comparison substance $\mathrm{As}_{2} \mathrm{O}_{3}$. The second phase could not be followed.

Gerhardsson et al (4) compared concentrations of antimony in lung tissues from a group of deceased smelter workers with a nonexposed reference group from a nearby area. The antimony concentrations for the smelters were 12 times higher than for the referents. Decreasing antimony concentrations with time (up to 20 years) after the cessation of exposure was not observed, a finding indicating a long biological half-time.

Cigarette smoke contains significant amounts of antimony (9). Thus smoking habits can contribute to higher concentrations of antimony in the lung tissues of exposed workers.

In summary the present studies have demonstrated a low solubility of airborne antimony-containing dust collected in an arsenic refinery. A long biological half-time was estimated by external lung clearance measurements in hamsters and implies a risk of accumulation in the lungs which should be taken into account when workers are exposed over many years.

The experimental set-up used in this study provides a method for determining the retention characteristics of various elements contained in airborne dust collected from ambient or workroom air. Information obtained by this method is of interest also in relation to long-term animal studies of the development of lung cancer and bronchogenic carcinomas, for which the intratracheal exposure route is often used.

\section{Acknowledgments}

Financial support was given by the Swedish Work Environment Fund, project no 80/107. Technical assistance by Ms S Sandberg is gratefully acknowledged.

We are grateful to Professor PO Wester for his support and for his critical reading of the manuscript.

\section{References}

1. Brune D, Nordberg GF, Wester PO. Distribution of $\mathbf{2 3}$ elements in the kidney, liver and lungs of workers from a smeltery and refinery in north Sweden exposed to a number of elements and of a control group. Sci Total Environ 16 (1980) 13-35.

2. Brune D, Nordberg GF, Wester PO, Bivered B. Accumulation of heavy metals in tissues of industrially exposed workers. In: International Atomic Energy Agency. Nuclear activation techniques in the life sciences. Vienna 1979. (IAEA-SM-227/12).

3. Felicetti SW, Thomas RG, McClellan RO. Retention of inhaled antimony-124 in the beagle dog as a function of temperature of aerosol formation. Health Phys 26 (1974) 525-531.

4. Gerhardsson L, Brune D, Nordberg GF, Wester PO. Antimony in lung, liver and kidney tissue from deceased smelter workers. Scand J Work Environ Health 8 (1982) 201-208.

5. Holmqvist I. Occupational arsenical dermatitis: A study among employees at a copper ore smelting work including investigations of skin reactions to contact with arsenic compounds. Acta Derm Venereol 31 (1951): suppl 26.

6. Holmqvist I. An environmental-hygienic investigation of heavy metals in Västerbotten. Nord Hyg Tidskr (1974) 12-22.

7. Kanapilly GM, Raabe OG, Goh CHT, Chimenti RA. Measurement of in vitro dissolution of aerosol particles for comparison to in vivo dissolution in the lower respiratory tract after inhalation. Health Phys 24 (1973) 497-507.

8. Morrow PE, Gibb FR, Davies H, Fisher M. Dust removal from the lung parenchyma: An investigation of clearance stimulants. Toxicol Appl Pharmacol 12 (1968) 372-396.

9. Nadkarni RA, Ehmann WD. Transference studies of trace elements from cigarette tobacco into smoke condensate and their determination by neutron activation analysis. In: University of Kentucky. Proceedings tobacco health conference, Report 2. Lexington, KY 1970, pp 37-45.

10. Nordberg GF, Wester PO, Brune D. Tissue levels of 25 
elements in smelter workers. In: International Labour Organisation. Proceedings of international symposium control of air pollution in the working environment: Part III. Geneva 1978, pp 261-272.

11. Pershagen G, Lind B, Björklund N-E. Lung retention and toxicity of some inorganic arsenic compounds. Environ Res 29 (1982) 425-434.

12. Persson S-A, Ahlberg $M$, Berghem L, Könberg E, Bergman F, Nordberg GF. Långtids carcinogenesstudie på syrisk guldhamster - En jämförelse mellan partikulära emissioner från ett koleldat kraftverk och ett oljeeldat kraftvärmeverk - En utvärdering av resultat upp till och med 75 veckor. Project KHM, Statens Vattenfallsverk, 16287 Vällingby, Sweden 1983.

13. Pinto SS, McGill CM. Arsenic trioxide exposure in industry. Ind Med Surg 22 (1953) 281-287.

14. Saffiotti U, Cefis F, Kolb LH. A method for the experimental induction of bronchogenic carcinoma. Cancer Res 28 (1968) 104-124.

15. Samsahl K, Wester PO, Landström O. An automatic group separation system for the simultaneous determination of a great number of elements in biological material. Anal Chem 40 (1968) 181-187.

16. Sjöstrand B. Simultaneous determination of mercury and arsenic in biological and organic materials by activation analysis. Anal Chem 36 (1964) 814-819.

17. Smith TJ, Eatough DJ, Hansen LD, Mangelsen NF. The chemistry of sulfur and arsenic in airborne copper smelter particulates. Bull Environ Contam Toxicol 15 (1976) 651-659.

18. Weast RC. Table of isotopes, section B. In: Weast RC, Astle MJ, ed. Handbook of chemistry and physics. 61st edition. CRC Press, Boca Raton, FL 1980.

19. Wester PO, Brune D, Nordberg GF. Arsenic and selenium in lung, liver and kidney tissue from dead smelter workers. Br J Ind Med 38 (1981) 179-184.

Received for publication: 6 June 1983 